\title{
ATP: Creatine Phosphotransferase in the Diagnosis of Acute Chest Pain
}

\author{
P. D. GRIFFITHS \\ From Herts and Essex General Hospital (Harlow Group of Hospitals), Bishop's Stortford, Herts.
}

A common problem in clinical medicine is the diagnosis of acute chest pain. Usually, the history, clinical findings, and electrocardiographic evidence are sufficient to enable the clinician to reach a confident diagnosis. Some cases, however, have atypical features or show an electrocardiogram difficult of interpretation, because of previous infarction, left bundle-branch block, previous left ventricular strain, arrhythmias, or changes due to digitalis therapy. In such instances, the clinician may seek the aid of the clinical chemist.

The laboratory methods most likely to be of assistance are assays of the activity of various enzymes which are normally present in low concentration in the serum, but in high concentration in cardiac muscle, e.g. the transaminases (aminotransferases), which are the most generally used, lactate dehydrogenase (or one of its iso-enzymes " $\alpha$-hydroxybutyrate dehydrogenase"), aldolase, malate dehydrogenase, phosphohexose isomerase, and creatine kinase (ATP: creatine phosphotransferase).

During a study of creatine kinase assay in clinical medicine, inter alia, the problem of the biochemical diagnosis of acute chest pain was examined. A new technique must be proved superior to the older ones before it can replace an established method. Therefore, creatine kinase $(\mathrm{CK})$ was compared with two tried methods, the transaminases (SGOT, SGPT) (Karmen, Wróblewski, and LaDue, 1955) and the " $\alpha$-hydroxybutyrate dehydrogenase" (SHBD) isoenzyme of lactate dehydrogenase (Elliott and Wilkinson, 1961).

\section{SUBJECTS AND METHODS}

Sera from 145 patients presenting with acute chest pain were examined by the three enzymatic assays. No

Received July 14, 1965. selection of patients was exercised by the author, and the clinical diagnosis and electrocardiographic interpretations were those of the clinician concerned.

(1) The transaminases, SGOT and SGPT, were estimated by a modification of the colorimetric method of Reitman and Frankel (1957).

(2) " $\alpha$-hydroxybutyrate dehydrogenase" activity was assayed by the colorimetric technique of Rosalki (1962).

(3) Creatine kinase was estimated by a modification of the colorimetric method of Ennor and Rosenberg (1954) for tissue extracts. This method (Griffiths, 1965a), which is particularly well suited to carrying out large batches of estimations, depends on the measurement of the creatine formed during the course of the reaction.

Apart from the transaminases, in which the familiar Karmen-Wróblewski units have been retained, the results are expressed in International units. The normal range of values for each parameter is shown in the Figure.

\section{RESULTS}

Table I summarizes the results which are classified as raised, equivocal, or normal, in the 145 patients. All three estimations could not be performed in every case (e.g. hæmolysed sera are unsuitable for the transaminase and dehydrogenase assays). All three methods were highly successful in the diagnosis of myocardial infarction, but in the other conditions, i.e. coronary insufficiency, angina of effort, dissecting aneurysm of the aorta, tachycardia, pulmonary infarction, pneumothorax, and chest pain of uncertain ætiology, results were variable.

Myocardial Infarction. The data from the 79 patients suffering from a myocardial infarction have been assembled in the Figure to demonstrate the pattern of behaviour of each of the serum enzymes. SGOT rises early in the illness, reaches a peak by the second day, and is usually normal by the 5th or 6th day. CK follows a similar course becoming 

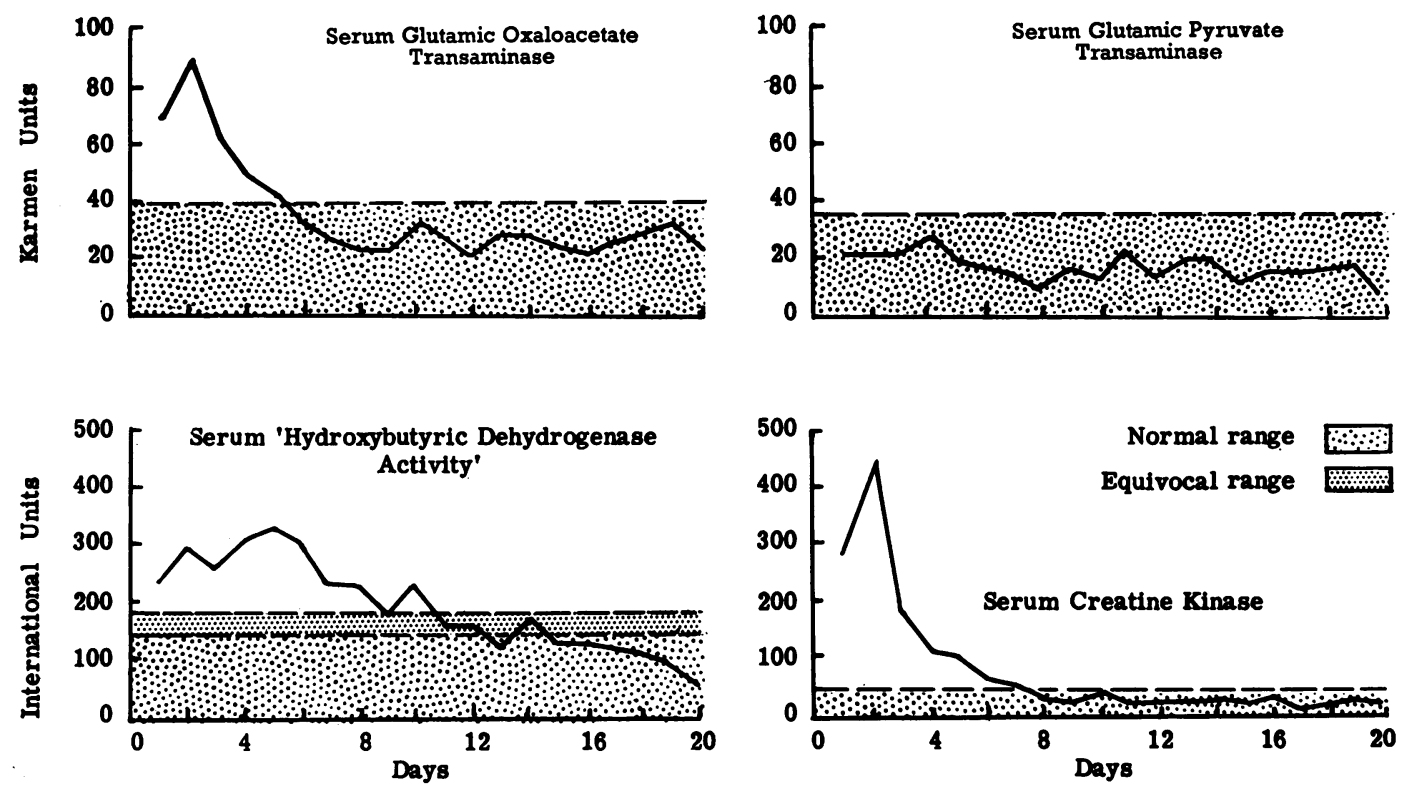

FIG. 1.-Serum enzyme levels following acute myocardial infarction-data from 79 patients.

TABLE I

SERUM ENZYMES IN ACUTE CHEST PAIN (145 PATIENTS)*

\begin{tabular}{|c|c|c|c|c|c|}
\hline Final clinical diagnosis & & Type of result & $\begin{array}{l}\text { Glutamic oxaloacetate } \\
\text { transaminase }\end{array}$ & $\begin{array}{l}\text { "Hydroxybutyrate } \\
\text { dehydrogenase" }\end{array}$ & Creatine kinase \\
\hline Myocardial infarction (79 patients) & .. & $\begin{array}{l}\text { Raised } \\
\text { Equivocal } \\
\text { Normal } \\
\text { Not done }\end{array}$ & $\begin{array}{c}57 \\
5 \\
13 t \\
4\end{array}$ & $\begin{array}{l}54 \\
11 \\
4 \ddagger \\
10\end{array}$ & $\begin{array}{c}72 \\
2 \\
45 \\
1\end{array}$ \\
\hline Coronary insufficiency (18 patients) & .. & $\begin{array}{l}\text { Raised } \\
\text { Equivocal } \\
\text { Normal } \\
\text { Not done }\end{array}$ & $\begin{array}{r}2 \\
2 \\
14 \\
0\end{array}$ & $\begin{array}{r}1 \\
1 \\
14 \\
2\end{array}$ & $\begin{array}{r}2 \\
1 \\
15 \\
0\end{array}$ \\
\hline Angina of effort (9 patients) $\quad \ldots$ & .. & $\begin{array}{l}\text { Raised } \\
\text { Equivocal } \\
\text { Normal } \\
\text { Not done }\end{array}$ & $\begin{array}{l}0 \\
1 \\
6 \\
2\end{array}$ & $\begin{array}{l}0 \\
1 \\
6 \\
2\end{array}$ & $\begin{array}{l}0 \\
2 \\
6 \\
1\end{array}$ \\
\hline Dissecting aortic aneurysm (2 patient & & $\begin{array}{l}\text { Raised } \\
\text { Equivocal } \\
\text { Normal } \\
\text { Not done }\end{array}$ & $\begin{array}{l}0 \\
0 \\
2 \\
0\end{array}$ & $\begin{array}{l}0 \\
0 \\
1 \\
1\end{array}$ & $\begin{array}{l}2 \\
0 \\
0 \\
0\end{array}$ \\
\hline Tachycardia (5 patients) & .. & $\begin{array}{l}\text { Raised } \\
\text { Equivocal } \\
\text { Normal } \\
\text { Not done }\end{array}$ & $\begin{array}{l}2 \\
1 \\
1 \\
1\end{array}$ & $\begin{array}{l}0 \\
1 \\
2 \\
2\end{array}$ & $\begin{array}{l}\mathbf{5} \\
\mathbf{0} \\
\mathbf{0} \\
\mathbf{0}\end{array}$ \\
\hline Pulmonary infarction ( 3 patients) & .. & $\begin{array}{l}\text { Raised } \\
\text { Equivocal } \\
\text { Normal } \\
\text { Not done }\end{array}$ & $\begin{array}{l}1 \\
0 \\
2 \\
0\end{array}$ & $\begin{array}{l}0 \\
0 \\
2 \\
1\end{array}$ & $\begin{array}{l}\mathbf{0} \\
\mathbf{1} \\
\mathbf{2} \\
\mathbf{0}\end{array}$ \\
\hline Pneumothorax (1 patient) & .. & $\begin{array}{l}\text { Raised } \\
\text { Equivocal } \\
\text { Normal } \\
\text { Not done }\end{array}$ & $\begin{array}{l}0 \\
0 \\
1 \\
0\end{array}$ & $\begin{array}{l}0 \\
0 \\
0 \\
1\end{array}$ & $\begin{array}{l}0 \\
0 \\
1 \\
0\end{array}$ \\
\hline $\begin{array}{c}\text { Chest pain of uncertain ætiology } \\
\begin{array}{c}\text { (28 patients) } \\
.\end{array}\end{array}$ & $\cdots$ & $\begin{array}{l}\text { Raised } \\
\text { Equivocal } \\
\text { Normal } \\
\text { Not done }\end{array}$ & $\begin{array}{r}6 \\
2 \\
19 \\
1\end{array}$ & $\begin{array}{r}2 \\
3 \\
9 \\
14\end{array}$ & $\begin{array}{r}4 \\
3 \\
20 \\
1\end{array}$ \\
\hline
\end{tabular}

* Estimations were performed within 72 hours of the onset of symptoms.

+9 more than 72 hours after onset of symptoms.

₹ 2 during first 24 hours after onset of symptoms. 
TABLE II

SERUM ENZYMES IN PATIENTS WITH MYOCARDIAL INFARCTION IN WHOM ELECTROCARDIOGRAPHIC CHANGES ARE OBSCURED BY OTHER EVENTS *

\begin{tabular}{|c|c|c|c|c|}
\hline Case No. & & $\begin{array}{c}\text { Glutamic oxaloacetate } \\
\text { transaminase } \\
\text { (Karmen units) }\end{array}$ & $\begin{array}{c}\text { "Hydroxybutyrate dehydrogenase" } \\
\text { (International units) }\end{array}$ & $\begin{array}{c}\text { Creatine kinase } \\
\text { (International units) }\end{array}$ \\
\hline $\begin{array}{l}1 \\
2 \\
3 \\
4 \\
5\end{array}$ & & $\begin{array}{l}58 \\
62 \\
85 \\
58 \\
68\end{array}$ & $\begin{array}{l}185 \\
235 \\
820 \\
245 \\
285\end{array}$ & $\begin{array}{l}640 \\
170 \\
290 \\
190 \\
510\end{array}$ \\
\hline $\begin{array}{r}6 \\
7 \\
8 \\
9 \\
10\end{array}$ & & $\begin{array}{c}62 \\
65 \\
82 \\
22 \\
(\operatorname{after} 72 \mathrm{hr} .) \\
50\end{array}$ & $\begin{array}{r}227 \\
190 \\
295 \\
470 \\
\\
95\end{array}$ & $\begin{array}{c}125 \\
270 \\
215 \\
13 \\
\text { after } 72 \mathrm{hr} . \\
80\end{array}$ \\
\hline $\begin{array}{l}11 \\
12 \\
13 \\
14 \\
15\end{array}$ & . & $\begin{array}{c}59 \\
45 \\
40 \\
28 \\
29 \\
\text { (at } 72 \mathrm{hr} . \text { ) }\end{array}$ & $\begin{array}{c}150 \\
125 \\
80 \\
152 \\
204 \\
\text { (at } 72 \mathrm{hr} . \text { ) }\end{array}$ & $\begin{array}{c}140 \\
60 \\
92 \\
85 \\
60 \\
\text { (at } 72 \mathrm{hr} . \text { ) }\end{array}$ \\
\hline Upper limit of normal & $\cdots$ & 40 & $\begin{array}{c}180 \\
(140-180 \text { equivocal })\end{array}$ & $\begin{array}{c}50 \\
\text { (non-ambulant patients) }\end{array}$ \\
\hline
\end{tabular}

* Specimens taken within $\mathbf{7 2}$ hours of the onset of the symptoms.

normal by the 6 th or 7 th day. The rise in $\mathrm{CK}$ is more marked than that of SGOT. SGPT is usually little affected by the illness, though rises occur in some subjects. SHBD reaches its peak rather later, tends to increase to a smaller degree than SGOT, but remains high much longer, returning to normal levels at about the 13th day. Allowing for proper timing of specimen collection in relation to the onset of symptoms, the success rate for SGOT, CK, and SHBD was 87, 96, and 97 per cent respectively.

The patients of most interest are those with equivocal electrocardiograms: 15 patients fell into this category, and the results are shown in Table II. Had a combination of two tests been used, either SGOT or CK for the patients tested early in the course of the illness and SHBD for those tested later, 12 would have been diagnosed correctly biochemically, doubt remaining in only 3 cases.

There was no correlation between the degree of rise in the CK level and the ultimate fate of the patient, e.g. two patients succumbed within a few days of the infarction; one showed a moderate rise to 171 units, whereas the other achieved a peak level of 2400 units.

Other Causes of Acute Chest Pain. There is good agreement between the three enzymic parameters in the coronary insufficiency, angina of effort, pulmonary infarction, pneumothorax, and the undiagnosed cases. The findings differ in the patients with tachycardia and dissecting aneurysm of the aorta, where only CK was raised consistently.

\section{Discussion}

Myocardial Infarction. Only in those cases in which doubt exists as to the diagnosis are biochemical tests important. The results obtained with the transaminases agree with those of many other workers (e.g. Agress, 1959), and the only points worthy of reiteration are, first, the importance of correct timing of the specimens in relation to the onset of the symptoms, and, secondly, that the test lacks specificity, as abnormal levels of SGOT occur in a great variety of conditions and even in normal subjects. Nevertheless, experience shows the test to be a valuable diagnostic aid provided it is used correctly and the results are interpreted carefully in the light of the clinical findings.

The SHBD results are substantially in agreement with those of other workers (e.g. Elliott and Wilkinson, 1961). Although not specific for myocardial infarction (Elliott and Wilkinson, 1963), the test is more specific than. SGOT in that it measures mainly the electrophoretically fastest migrating isoenzyme of cardiac muscle, and the longer period of raised serum enzyme activity following an infarction is an advantage. Its biggest drawback is the ease with which enzyme contained in the red cell is released into the serum (Smith, 1964), a drawback shared by SGOT to a lesser degree (Karmen et al., 1955). Creatine kinase, on the other hand, is present in human red cells in negligible amounts (Solvonuk, McRae, and Collier, 1956).

The changes in serum $\mathrm{CK}$ activity closely parallel those of SGOT. However, the liver damage, which is not uncommon following a myocardial 
infarction (Rosin, 1961), leads to a prolongation of the high levels of SGOT and a rise of SGPT: a modified pattern does not occur with $\mathrm{CK}$ as serum levels of this enzyme are unaffected by liver damage. High levels of serum CK occur in the dystrophies (Ebashi et al., 1959) and in hypothyroidism (Graig and Ross, 1963), but in the event of chest pain occurring in such patients serial estimations will resolve the problem. The transient nature of the serum enzyme level compares unfavourably with SHBD, but it is a more sensitive and more specific test than SGOT. Unfortunately, the assay technique is more difficult and laborious than that of the transaminases.

Creatine kinase, in common with the other two parameters, appears to have little prognostic value.

Most clinicians and pathologists are so familiar with the use of transaminases in myocardial infarction that they have come to terms with the test's limitations. The other enzyme tests are less well known, and their advantages over SGOT probably are insufficient to warrant replacing this standard biochemical aid to the diagnosis of myocardial infarction.

Other Causes of Acute Chest Pain. (1) Acute coronary insufficiency. This often presents a troublesome diagnostic problem. The patient not infrequently has had a previous infarction or similar episode, a psychological overlay is not uncommon, and the electrocardiogram generally shows a strain or ischæmic pattern. The diagnosis may never be fully resolved, thus contributing to the relatively large number of patients in Table I who have been designated as chest pain of uncertain ætiology. There is little to choose between the three enzyme tests in this instance. Of the two patients with abnormal CK levels, one had an equivocal electrocardiogram, a raised erthrocyte sedimentation rate and white cell count, the last two settling with bedrest, and a raised SGOT. SHBD was normal. Two months later the patient was readmitted with an unequivocal myocardial infarction. The second, who had suffered a previous infarction, was admitted the third day following the onset of his symptoms. The SGOT level was marginal and the SHBD normal. CK was mildly raised for a resting patient but of the order usually found at this stage in myocardial infarction. The patient with the raised SHBD was admitted 10 days after the onset of her symptoms, so that a normal transaminase and kinase were to be expected. The electrocardiogram showed ischæmic changes. As the dehydrogenase remained abnormal for three days, one wonders if the enzyme test might not have been the more accurate indicator.
(2) Angina of effort. No clearly abnormal enzyme levels were recorded in any of the patients, an observation in agreement with those of other workers using the dehydrogenase and transaminase tests. The two with marginal levels of CK both had specimens taken soon after admission and the levels became normal after a few hours' rest. Ambulant patients tend to have higher levels than resting patients (Griffiths, 1965b), which may explain these results.

(3) Dissecting aneurysm of the aorta. Both patients had abnormal levels of CK suggesting an incorrect diagnosis of myocardial infarction (the diagnosis was proven at necropsy). SGOT in this condition is known to give variable results, so that with the limited information available it seems unlikely that existing biochemical methods will distinguish between an infarction and dissecting aortic aneurysm.

(4) Tachycardia. This group of patients with severe tachycardia are very interesting, for all had abnormal CK levels. Two also had a raised SGOT. Prolonged exercise considerably increases the serum activities of some enzymes, expecially CK (Griffiths, 1965b), and a sustained tachycardia could be regarded as prolonged exercise of cardiac as opposed to skeletal muscle.

Pulmonary Infarction. The results in these patients do not suggest that the biochemical tests are likely to distinguish unequivocally between pulmonary and myocardial infarction. Transaminase has failed in this respect. Claims that lactate dehydrogenase is more successful have been made (Wacker and Snodgrass, 1960), and abnormal levels of SHBD in this condition have been recorded recently (Stuart et al., 1965), confirming doubts as to the value of enzyme tests in this condition.

Acute Chest Pain of Uncertain Etiology. The high proportion of patients in whom no final diagnosis was reached is an indication of the difficulties inherent in this problem. A majority (Table I) had normal serum enzyme levels, but in the others the biochemical and clinical findings were equally equivocal.

Thus, the results of enzyme tests in acute chest pain are seen to show inconsistencies. The diagnostic problem can be considerable, and though much light on the diagnosis may be thrown by all or any of these tests in myocardial infarction the view that "the ideal biochemical test for myocardial infarction does not exist" (Lancet, 1958) remains 
uncontradicted. Nevertheless, Elliott and Wilkinson's claim (1962) that the SHBD assay is "the most appropriate enzyme test at present available for the confirmation of suspected myocardial infarction" is difficult to resist, providing the most stringent precautions are observed when handling the blood samples.

\section{SUMMARY}

The sera of 145 patients presenting with acute chest pain were examined for glutamic oxaloacetate transaminase, " $\alpha$-hydroxybutyrate dehydrogenase", and creatine kinase activities. The transaminase activity was raised in 87 per cent, the dehydrogenase activity in 97 per cent, and the creatine kinase activity in 96 per cent of cases of myocardial infarction.

Raised serum enzyme levels were obtained on occasions in other conditions presenting with acute chest pain, but both patients with dissecting aortic aneurysms, and all 5 with severe tachycardia, had raised serum levels of creatine kinase.

The view is expressed that though assays of the dehydrogenase and kinase are superior to the glutamic oxaloacetate transaminase as diagnostic aids for cases of myocardial infarction, it is doubtful if there is sufficient improvement to warrant replacing this familiar and well-tried test, which is in current use in most clinical laboratories, by one of the newer techniques.

I am indebted to Dr. W. H. H. Merivale, Director of the Department of Clinical Pathology, Guy's Hospital, S.E.1 and to Dr. E. N. Allott, late director of the Group Laboratory, Lewisham Hospital, S.E.13, in whose departments the work was carried out, to the clinical Staff of Guy's Hospital, and to Dr. H. Lehmann, Addenbrooke's Hospital, Cambridge, for their support in this study.

This paper is based on work included in a thesis for the M.D. degree of the University of London.

\section{REFERENCES}

Agress, C. M. (1959). Evaluation of the transaminase test. Amer. F. Cardiol., 3, 74.

Ebashi, S., Toyokura, Y., Momoi, H., and Sugita, H. (1959). High creatine-phosphokinase activity of sera of progressive muscular dystrophy. F. Biochem. (Tokyo), 46, 103.

Elliott, B. A., and Wilkinson, J. H. (1961). Serum “ $\alpha$ hydroxybutyric dehydrogenase" in myocardial infarction and in liver disease. Lancet, 1, 698.

- , and - (1962). The relative efficiencies of some serum-enzyme tests in the diagnosis of myocardial infarction. Lancet, 2, 71.

,$--(1963)$. The serum " $\alpha$-hydroxybutyrate dehydrogenase" in diseases other than myocardial infarction. Clin. Sci., 24, 343.

Ennor, A. H., and Rosenberg, H. (1954). Some properties of creatine phosphokinase. Biochem. f., 57, 203.

Graig, F. A., and Ross, G. (1963). Serum creatine-phosphokinase in thyroid disease. Metabolism, 12, 57.

Griffiths, P. D. (1965a). ATP: creatine phosphotransferase in skeletomuscular disorders with special reference to Duchenne muscular dystrophy. Guy's Hosp. Rep. In the press.

- (1965b). Serum creatine kinase and exercise. Brit. med. F., 2, 157.

Karmen, A., Wróblewski, F., and LaDue, J. S. (1955). Transaminase activity in human blood. $\mathcal{F}$. clin. Invest., 34, 126.

Lancet (1958). Leader. Diagnosis of myocardial infarction. $1,145$.

Reitman, S., and Frankel, S. (1957). A colorimetric method for the determination of serum glutamic oxalacetic and glutamic pyruvic transaminases. Amer. F. clin. Path., 28, 56.

Rosalki, S. B. (1962). A simple colorimetric method for the determination of serum alpha-hydroxybutyric dehydrogenase activity. F. clin. Path., 15, 566.

Rosin, A. J. (1961). Liver function in acute myocardial infarction. A study using bromsulphthalein test. Brit. med. F., 2, 675.

Smith, A. F. (1964). Serum-enzymes in myocardial infarction. Lancet, $2,1143$.

Solvonuk, P. F., McRae, S. C., and Collier, H. B. (1956). Creatine phosphokinase activity of mammalian erythrocytes. Canad. F. Biochem., 34, 481.

Stuart, J., Crawford, I. C., Forshall, J., and Owen, J. A. (1965). Serum hydroxybutyrate dehydrogenase in myocardial infarction. Brit. med. F., 1, 423.

Wacker, W. E. C., and Snodgrass, P. J. (1960). Serum LDH activity in pulmonary embolism diagnosis. $\mathcal{f}$. Amer. med. Ass., 174, 2142. 